\title{
PENGARUH PARTISIPASI ANGGARAN TERHADAP KINERJA MANAJERIAL DENGAN KOMITMEN ORGANISASI DAN GAYA KEPEMIMPINAN SEBAGAI VARIABEL MODERATING (Studi Empiris Pada Rumah Sakit Di Pekanbaru)
}

\author{
${\text { Faizah Kamilah }{ }^{*} \text {, Taufeni Taufik }{ }^{2} \text {, dan Edfan Darlis² }}^{2}$ \\ ${ }^{1}$ Program Studi Magister Akuntansi Pasca Sarjana Universitas Riau, Pekanbaru \\ ${ }^{2}$ Fakultas Ekonomi Universitas Riau, Pekanbaru \\ Email :fazahkamilah76@yahoo.com
}

\begin{abstract}
Abstrak: Penelitian ini bertujuan menguji pengaruh partisipasi anggaran terhadap kinerja manajerial dengan komitmen organisasi dan gaya kepemimpinan sebagai variabel moderating pada Rumah Sakit di Pekanbaru. Populasi dalam penelitian ini adalah 21 Rumah Sakit pada Kota Pekanbaru. Pengumpulan data dilakukan dengan cara membagikan kuesioner kepada 84 responden, dan hanya 80 kuesioner yang dapat digunakan dalam penelitian ini. Metode analisis data yang digunakan dalam penelitian ini adalah regresi berganda. Hasil penelitian ini menunjukkan bahwa partisipasi penyusunan anggaran berpengaruh signifikan terhadap kinerja manajerial. Komitmen organisasi dapat memoderasi pengaruh partisipasi anggaran terhadap kinerja manajerial. Gaya kepemimpinan berorientasi tugas dapat memoderasi pengaruh partisipasi penyusunan anggaran terhadap kinerja manajerial. Gaya kepemimpinan berorientasi hubungan dapat memoderasi pengaruh partisipasi penyusunan anggaran terhadap kinerja manajerial. Hasil koefisien determinasi untuk hipotesis pertama sebesar 69\%, hipotesis kedua sebesar 65\%, hipotesis ketiga sebesar 64\%, dan hipotesis keempat sebesar $65 \%$. Sedangkan sisanya dijelaskan oleh variabel seperti seperti wewenang, kecukupan anggaran, budaya organisasi, komitmen tujuan anggaran, desentralisasi, locus of control dan lainlain.

Kata Kunci: Partisipasi Penyusunan Anggaran, Komitmen Organisasi, Gaya Kepemimpinan Berorientasi Tugas, Gaya Kepemimpinan Berorientasi Hubungan, Kinerja Manajerial.
\end{abstract}

\section{PENDAHULUAN}

Kinerja manajerial merupakan salah satu faktor yang dapat meningkatkan keefektifan organisasional. Dengan melakukan pengukuran kinerja maka dapat memastikan apakah pengambilan keputusan dilakukan secara tepat dan objektif. (Bastian 2005). Kinerja manajerial dipengaruhi oleh beberapa faktor seperti partisipasi penyusunan anggaran, komitmen organisasi, gaya kepemimpinan barorientasi tugas, gaya kepemimpinan berorientasi hubungan dan sebagainya. Dari beberapa hasil penelitian terdahulu, terbukti bahwa variabel partisipasi penyusunan anggaran lebih banyak diteliti pengaruhnya terhadap kinerja manajerial. Hal ini dikarenakan anggaran mempunyai dampak langsung 
terhadap manusia terutama bagi yang terlibat didalam penyusunan anggaran (Siegel dan Marconi, 1989). Adanya keterlibatan manajer dalam penyusunan anggaran yang biasa disebut dengan penyusunan anggaran secara partisipatif maka kinerja manajerial akan lebih meningkat (Milani, 1975).

Peran partisipasi penyusunan anggaran sebagai variabel yang secara langsung dapat mempengaruhi kinerja manajerial telah dibuktikan oleh penelitian yang dilakukan oleh Brownell dan McInnes (1986), Yusfaningrum dan Ghozali (2005). Namun Beberapa penelitian yang lain tidak menemukan bukti bahwa partisipasi penyusunan anggaran mempunyai pengaruh terhadap kinerja manajerial (Kenis, 1979, Brownel and Hirst, 1986, Sinuraya, 2009). Ketidak konsistenan hasil penelitian terutama mengenai peranan variabel partisipasi penyusunan anggaran sebagai variabel independen yang dapat langsung mempengaruhi kinerja manajerial menyebabkan penelitian lebih lanjut mengenai partisipasi penyusunan anggaran.

Pengaruh penganggaran partisipasi pada kinerja manajerial merupakan tema yang menarik dalam penelitian akuntansi manajemen. Brownell (1986) menyebutkan dua alasan yaitu: (a) partisipasi dinilai sebagai pendekatan manajerial yang dapat meningkatkan kinerja anggota organisasi, dan (b) berbagai penelitian yang menguji hubungan antara partisipasi dan kinerja hasilnya saling bertentangan.

Govindarajan dalam Supriyono (2005) menyatakan bahwa untuk mengatasi ketidakkonsistenan hasil-hasil riset tersebut, diperlukan pendekatan kontinjensi (Contingency). Pendekatan ini memberikan suatu gagasan bahwa hubungan antara partisipasi penganggaran dan kinerja manajerial diduga dipengaruhi oleh faktor atau variabel yang bersifat kondisional.

Variabel komitmen organisasi dan gaya kepemimpinan adalah variabel yang dapat memoderasi hubungan antara partisipasi penyusunan anggaran dengan kinerja manajerial. Komitmen organisasi merupakan dorongan dari dalam individu untuk berbuat sesuatu agar dapat menunjang keberhasilan organisasi sesuai dengan tujuan yang telah direncanakan dan tidak lebih mengutamakan kepentingannya sendiri (Weiner, dalam Corynata, 2004). Gaya kepemimpinan merupakan norma perilaku yang digunakan oleh seseorang pada saat orang tersebut mencoba mempengaruhi perilaku dengan orang lain seperti yang ia lihat (Thoha, 2008). Efektivitas partisipasi penganggaran sangat dipengaruhi oleh gaya kepemimpinan manajemen (Fiedler dan Chandra dalam Sumarno, 2005). Untuk itulah dalam penelitian ini menggunakan variabel moderasi komitmen organisasi dan gaya kepemimpinan.

Ghozali dan Yusfaningrum (2005) melakukan penelitian tentang analisis pengaruh partisipasi anggaran terhadap kinerja manajerial melalui komitmen tujuan anggaran dan job relevant information sebagai variabel intervening. 
Penelitian ini menunjukkan partisipasi anggaran berpengaruh positif dan signifikan terhadap kinerja manajerial.

Komitmen organisasi sangat penting pengaruhnya terhadap pekerjaan agar tercipta kondisi kerja yang kondusif sehingga organisasi dapat berjalan secara efektif dan efisien. Dapat dikatakan bahwa komiten adalah kerelaan untuk bekerja keras dan memberikan energi serta waktu untuk sebuah pekerjaan atau aktivitas. Komitmen organisasi yang kuat akan mendorong individu berusaha keras mencapai tujuan organisasi. Partisipasi anggaran akan menimbulkan adanya kecukupan anggaran dan kemudian mempengaruhi kinerja (Randall, 1990 dalam Sumarno, 2005).

Sardjito dan Muthaher (2007) melakukan penelitian tentang pengaruh partisipasi anggaran terhadap kinerja aparat pemerinatah daerah dengan budaya organisasi dan komitmen organisasi sebagai variabel moderating. Penelitian ini menunjukkan terdapat pengaruh yang signifikan antara komitmen organisasi dalam memoderasi partisipasi penyusunan anggaran terhadap kinerja aparat pemerintah daerah. Hasil ini menunjukkan Semakin tinggi komitmen organisasi akan menyebabkan peningkatan kerja aparat pemerintah daerah dalam berpartisipasi penyusunan anggaran.

Gaya kepemimpinan mempengaruhi lingkungan perencanaan organisasi, teori X Mc Gregor dalam Lubis (2010) menjelaskan gaya kepemimpinan yang otoriter dan dikendalikan secara ketat dimana kebutuhan akan efisiensi dan pengendalian akan efisiensi dan pengendalian mengharuskan pendekatan manajerial tersebut untuk berurusan dengan bawahannya. Untuk memantau kinerja bawahan para pemimpin menugaskan staf mereka untuk mengumpulkan informasi yang memungkin dilakukannya pengawasan secara tidak langsung. Diterapkan pada fungsi perencanaan, teori X mengimplikasikan bahwa anggaran akan disusun oleh manajemen puncak dan dikenakan pada manajemen tingkat bawah, dengan demikin dalam gaya kepemimpinan otoriter anggaran dipandang sebagai alat pengendalian manajemen (Lubis, 2010).

Menurut Daft (2010) terdapat model Friedler yang menunjukkan bahwa efektifitas kepemimpinan tergantung dari kecocokan antara gaya kepemimpinan dengan situasi yang dihadapi pemimpin. Dalam hal ini, gaya kepemimpinan cenderung bersifat tetap yang melekat pada diri pemimpin, dan dapat dibedakan dalam dua kategori utama yaitu gaya berorientasi tugas yang mementingkan tugas pekerjaan atau otoritatif dan gaya berorientasi hubungan yang mementingkan hubungan kemanusiaan.

Sumarno (2005) melakukan penelitian tentang pengaruh komitmen organisasi dan gaya kepemimpinan terhadap hubungan antara partisipasi anggaran terhadap kinerja manajerial. Penelitian tersebut menunjukkan pengaruh gaya kepemimpinan terhadap hubungan antara partisipasi anggaran dan manajerial tidak signifikan. 
Nor (2007) melakukan penelitian tentang desentralisasi dan gaya kepemimpinan sebagai variabel moderating dalam hubungan antara partisipasi penyusunan anggaran dan kinerja manajerial. hasil penelitian ini menunjukkan bahwa kesesuain antara partisipasi penyusunan anggaran dengan faktor kontijen (gaya kepemimpinan) terhadap kinerja manajerial tidak signifikan.

\section{TELAAH PUSTAKA}

\section{Kinerja Manajerial}

Kinerja manajerial merupakan salah satu faktor yang dapat meningkatkan keefektifan organisasional. Mahoney et.al dalam Sumadiyah dan Susanta (2004) melihat kinerja manajer berdasar pada kemampuan manajer dalam melaksanakan tugas manajerialnya. Kinerja manajerial meliputi kemampuan manajer dalam: perencanaan, investigasi, pengkoordinasian, evaluasi, pengawasan, pemilihan staff, negoisasi, perwakilan dan kinerja secara menyeluruh telah ditetapkan.

\section{Partisipasi Anggaran}

Menurut Supriyono (2005) penganggaran partisipatif adalah suatu proses penyusunan anggaran yang melibatkan setiap manajer pusat pertanggung jawaban dan mereka memiliki kesempatan untuk menjelaskan dan memberikan alasan atas anggaran yang diusulkan. Partisipasi penganggaran didefinisikan sebagai suatu proses dimana kinerja individu akan dievaluasi, diberikan penghargaan, atau hukuman berdasarkan dari tingkat pencapaian target anggarannya (Chong dan Johnson, 2007).

\section{Komitmen Organisasi}

Komitmen organisasi menurut Weiner dalam Suryanawa (2008) adalah dorongan dari dalam individu untuk berbuat sesuatu agar dapat menunjang keberhasilan organisasi sesuai dengan tujuan dan lebih mengutamakan kepentingan organisasi dibandingkan dengan kepentingan sendiri.

\section{Gaya Kepemimpinan Berorientasi Tugas}

Gaya kepemimpinan berorientasi tugas yaitu pemimpin yang berorientasi pada tugas dan memperoleh kepuasan dari terlaksananya tugas-tugas. Pemimpin memotivasi dengan memenuhi kebutuhan psikologis seperti rasa percaya diri dan status yang dicapai melalui penyelesaian tugas-tugas, tidak melalui hubungan dengan bawahan .Ini tidak berarti pemimpin tidak bersahabat dan ramah terhadap bawahan, tetapi jika penyelesaian tugas terancam maka hubungan interpersonal yang baik tidak lagi menjadi hal yang penting (Daft, 2010).

\section{Gaya Kepemimpinan Berorientasi Hubungan}


Pemimpin yang berorientasi hubungan akan memotivasi dengan cara memenuhi kebutuhan sosial dan mengupayakan pencapaian hubungan antar pribadi yang baik dan pencapaian kedudukan pribadi yang menonjol. Jika pemimpin dapat mencapai tujuan diatas maka seorang pemimpin dapat mencapai tujuan sekundernya seperti status dan rasa percaya diri (Daft, 2010).

\section{Penelitian Terdahulu}

Soemarno (2005), Supriyono (2004), Suardana dan Suryanawa (2008), Corynta (2004), Sardjito dan Muthaher (2007), Putu dan Wayan (2009), menyatakan partisipasi penyusunan anggaran berpengaruh terhadap kinerja manajerial dan partisipasi penyusunan anggaran dengan dimoderasi oleh komitmen organisasi berpengaruh terhadap kinerja manajerial. Sedangkan Supriyono (2004), Suardana dan Suryanawa (2008) menyatakan partisipasi penyusunan anggaran dengan dimoderasi oleh komitmen organisasi tidak berpengaruh terhadap kinerja manajerial. Mediaty (2010) menyatakan partisipasi penyusunan anggaran dengan dimoderasi oleh gaya kepemimpinan berpengaruh terhadap kinerja manajerial, sedangkan Nor (2007) dan Soemarno (2005) menyatakan partisipasi penyusunan anggaran dengan dimoderasi oleh gaya kepemimpinan tidak berpengaruh terhadap kinerja manajerial

\section{KERANGKA PEMIKIRAN DAN HIPOTESIS}

\section{Pengaruh Partisipasi Anggaran Terhadap Kinerja Manajerial}

Anggaran yang telah disusun memiliki peranan sebagai perencanaan dan sebagai kriteria kinerja, yaitu anggaran dipakai sebagai suatu sistem pengendalian untuk mengukur kinerja manajer. Untuk mencegah dampak fungsional atau disfungsionalnya, sikap dan perilaku anggota organisasi dalam penyusunan anggaran, perlu melibatkan manajemen pada level yang lebih rendah sehingga anggaran partisipatif dapat dinilai sebagai pendekatan manajerial yang dapat meningkatkan kinerja setiap anggota organisasi (Sardjito dan Muthaher, 2007).

Supriyono (2005) mengungkapkan bahwa di Indonesia, hubungan antara partisipasi anggaran dengan kinerja manajer mempunyai hubungan positif secara signifikan. Manajer yang memiliki partisipasi anggaran yang tinggi akan lebih memahami tujuan anggaran. Karena kinerja manajer akan dinilai berdasarkan target anggaran yang bisa dicapai, manajer akan bersungguh-sungguh dalam penyusunan anggaran dan menyebabkan meningkatnya kinerja manajer tersebut.

\section{Komitmen Organisasi Berpengaruh Terhadap Hubungan Partisipasi Anggaran Dengan Kinerja Manajerial}

Komitmen organisasi adalah dorongan dari dalam individu untuk berbuat sesuatu agar dapat menunjang keberhasilan organisasi sesuai dengan tujuan dan 
lebih mengutamakan kepentingan organisasi dibandingkan dengan kepentingan sendiri. Dorongan yang ada pada setiap individu dapat mempengaruhi keberhasilan suatu organisasi, jika individu tersebut berpartisipasi dalam penyusunan anggaran akan turut meningkatkan kinerja manajerial (Bambang Sradjito dan Osmad Muthaher, 2007).

Wiener dalam Juli dan Suryanawa (2010) mendefinisikan komitmen organisasi sebagai dorongan dari dalam diri individu untuk berbuat sesuatu agar dapat menunjang keberhasilan organisasi sesuai dengan tujuan dan lebih mengutamakan kepentingan organisasi dibandingkan kepentingan sendiri. Dalam pandangan ini, individu yang memiliki komitmen yang tinggi akan lebih mengutamakan kepentingan organisasi nya dari pada kepentingan pribadi atau kelompoknya. Komitmen akan membuat organisasi lebih produktif dan profitable. Bagi individu dengan komitmen organisasi yang tinggi, pencapaian tujuan organisasi merupakan hal penting.

\section{Gaya Kepemimpinan Berorientasi Tugas Berpengaruh Terhadap Hubungan Partisipasi Anggaran Dengan Kinerja Manajerial.}

Gaya kepemipinan yang berorientasi tugas ini yaitu seperti terbuka, loyal, dapat dipercaya, sopan, ramah, kooperatif, jujur dan baik. Gaya kepemimpinan ini akan lebih fokus pada hasil akhir pekerjaan, apakah bawahan dapat menjalankan tugas dan tanggung jawab nya dengan baik dan benar sesuai dengan tujuan dan sasaran yang telah ditetapkan. Dalam hal ini atasan akan memotivasi bawahannya untuk bekerja lebih baik dan bertanggung jawab dalam proses penyusunan anggran. Dengan adanya keterlibatan bawahan dan atasan dalam proses penyusunan anggaran ini akan turut meningkatkan kinerja manajerial (Daft, 2010).

\section{Gaya Kepemimpinan Berorientasi Hubungan Berpengaruh Terhadap Hubungan Partisipasi Anggaran Dengan Kinerja Manajerial.}

Gaya kepemipinan yang berorientasi hubungan ini yaitu seperti menyenangkan, bersahabat, menerima, santai/ rileks, mendukung, harmonis dan riang. Gaya kepemimpinan ini akan lebih fokus pada hubungan atasan dengan bawahan dengan cara membuka lebar-lebar jalur komunikasi dan mendelegasikan tanggung jawab dan memberiak kesempatan kepada para bawahan untuk menggunakan potensi yang ia miliki dalam proses penyusunan anggaran. Hal ini sama dengan gaya kepemimpinan yang berorientasi tugas, dengan adanya keterlibatan bawahan dan atasan dalam proses penyusunan anggaran akan turut meningkatkan kinerja manajerial (Daft, 2010).

\section{Hipotesis Penelitian}

H1: partisipasi penyusunan anggaran berpengaruh positif terhadap kinerja manajerial. 
H2: Komitmen organisasi dapat memoderating pengaruh partisipasi penyusunan anggaran pada kinerja manajerial.

H3: Gaya kepemimpinan yang berorientasi tugas dapat memoderating pengaruh partisipasi penyusunan ganggaran pada kinerja manajerial.

H4: Gaya kepemimpinan yang berorientasi hubungan dapat memoderating pengaruh partisipasi penyusunan anggaran pada kinerja manajerial.

\section{METODOLOGI}

\section{Populasi dan Sampel}

Populasi dalam penelitian ini 21 rumah sakit di Pekanbaru. Pengambilan sampel dilakukan dengan menggunakan metode purposive sampling. Sedangkan responden dalam penelitian ini yaitu manajer tingkat menengah dan manajer tingkat bawah dari Rumah Sakit yang ada di Pekanbaru yaitu Manajer Keuangan, Manajer Pemasaran, Manajer Operasional dan Manajer Sumber Daya Manusia (SDM).

\section{Pengumpulan Data}

Data penelitian yang digunakan adalah data primer, yaitu data yang dikumpulkan dengan mengirimkan kuesioner atau daftar pertanyaan kepada para manajer di rumah sakit yang ada di Pekanbaru.

\section{Definisi Operasionalisasi Variabel dan Pengukurannya}

Kinerja manajerial merupakan salah satu faktor yang dapat meningkatkan keefektifan organisasional. Mahoney et.al (1963) dalam Sumadiyah dan Susanta (2004) melihat kinerja manajer yaitu berdasarkan pada kemampuan manajer dalam melaksanakan tugas manajerialnya. Kinerja manajerial diukur dengan menggunakan instrumen daftar pertanyaan yang dikembangkan oleh Mahoney et al. (1963). Kinerja manajerial dalam penelitian ini diukur dengan delapan dimensi kinerja yaitu: perencanaan, pengkoordinasian, evaluasi, pengawasan, pengaturan staf, negosiasi, perwakilan/ representasi dan kinerja secara keseluruhan.

Partisipasi anggaran adalah keterlibatan manajer dan luasnya pengaruh dalam proses penyusunan anggaran (Milani, 1975 dalam Supriyono 2005). Partisipasi anggaran diukur dengan menggunakan instrumen daftar pertanyaan yang disusun oleh Milani (1975). Instrumen pertanyaan pada variabel partisipasi anggaran antara lain mengenai seberapa besar keterlibatan para manajer dalam proses penyusunan anggaran, tingkat kelogisan alasan atasan untuk merevisi usulan anggaran yang dibuat manajer, intensitas manajer mengajak diskusi tentang anggaran, besarnya pengaruh manajer dalam anggaran, seberapa besar 
manajer merasa mempunyai kontribusi penting terhadap anggaran, serta frekuensi atasan meminta pendapat manajer dalam penyusunan anggaran.

Komitmen organisasi adalah kepercayaan yang kuat dan keterterimaan terhadap tujuan-tujuan dan nilai-nilai organisasi serta keinginan untuk berusaha mencapai tujuan organisasi tersebut (Porter et al., 1974dalam Supriyono, 2004). Komitmen organisasi diukur dengan menggunakan instrumen daftar pertanyaan yang dikembangkan oleh Mowday (1979) Dalam penelitian ini, komitmen organisasi dilihat dari beberapa hal berikut ini: usaha keras untuk menyukseskan organisasi, kebanggaan berkerja pada organisasi tersebut, kesediaan menerima tugas demi organisasi, kesamaan nilai individu dengan nilai organisasi, kebanggan menjadi bagian dari organisasi, organisasi merupakan inspirasi untuk melaksanaan tugas, senang atas pilihan bekerja di organisasi tersebut, perhatian terhadap nasib organisasi dan anggapan bahwa organisasinya adalah organisasi yang terbaik.

Gaya kepemimpinan adalah derajat hubungan antara manajer masingmasing departemen dengan teman sekerjanya. Penelitian ini menggunakan instrumen yang dikembangkan oleh Fiedler dan Yukl (1981) dan dikembangkan dalam penelitian Sumarno (2005) yang dikenal dengan LPC (Least Preferred Cowerker Scale). Kuesioner ini digunakan untuk mengukur dua gaya kepemimpinan dasar individu yaitu :

a. Berorientasi tugas atau kepemimpinan yang mengendalikan, dan menstruktur.

b. Berorientasi hubungan atau penuh perhatian.

\section{Analisis Data}

Menurut Ghozali (2005) Untuk menguji regresi dengan variabel moderating digunakan uji interaksi yang merupakan aplikasi khusus regresi berganda linear dimana persamaan regresi nya mengandung unsur interaksi (perkalian dua atau lebih variabel independen). Keempat hipotesis yang dikemukakan diuji dengan dengan persamaan regresi sebagai berikut :

Persamaan Regresi Pertama $Y=\alpha+\beta_{1} X_{1}+\varepsilon$

Persamaan Regresi Kedua $Y=\alpha+\beta_{1} X_{1}+\beta_{2} X_{2}+\beta_{4}\left(X_{1} X_{2}\right)+\varepsilon$

Persamaan Regresi Ketiga $Y=\alpha+\beta_{1} X_{1}+\beta_{3} X_{3}+\beta_{5}\left(X_{1} X_{3}\right)+\varepsilon$

Persamaan Regresi Keempat $Y=\alpha+\beta_{1} X_{1}+\beta_{4} X_{4}+\beta_{6}\left(X_{1} X_{4}\right)+\varepsilon$

Dimana:

Y : Kinerja Manajerial

$\mathrm{X}_{1} \quad$ : Partisipasi Penyusunan Anggaran

$\mathrm{X}_{2} \quad$ : Komitmen Organisasi

$\mathrm{X}_{3} \quad$ : Gaya Kepemimpinan Berorientasi Tugas

$\mathrm{X}_{4} \quad$ : Gaya Kepemimpinan Berorientasi Hubungan

$\mathrm{X}_{1} \mathrm{X}_{2} \quad$ : Interaksi antara $\mathrm{X}_{1}$ dan $\mathrm{X}_{2}$ 


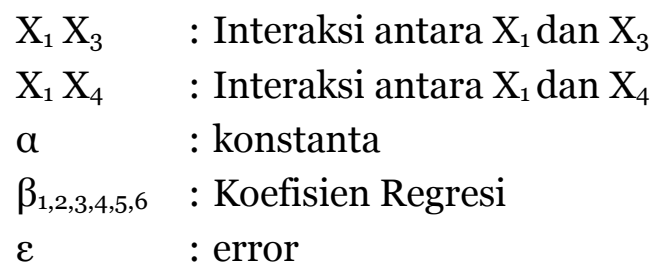

\section{HASIL PENELITIAN DAN PEMBAHASAN}

Penelitian ini menggunakan kuesioner untuk pengumpulan data yang dikirimkan kepada manajer rumah sakit Pekanbaru. Pengiriman daftar pertanyaan diantar langsung untuk menjaga kepastian sampainya daftar pertanyaan ke tangan responden. Dari 84 kuesioner yang dikirimkan, kuesioner yang kembali sebanyak 80 (95\%). Kuesioner yang dapat diolah sebanyak 80 (95\%).

Kinerja manajerial, dalam penelitian ini untuk menilai kinerja manajerial digunakan 15 pertanyaan. Total skor jawaban responden diperoleh sebesar 6231 dengan nilai minimal sebesar 3600, nilai maksimal sebesar 8400, dan rata-rata skor sebesar 5,2 dan kriteria posisi sebesar 74,17\%. Kriteria 74,17\% termasuk di posisi $69 \%-83 \%$ (sangat baik).

Partisipasi anggaran, dalam penelitian ini untuk menilai partisipasi anggaran digunakan 6 pertanyaan. Total skor jawaban responden diperoleh sebesar 2501 dengan nilai minimal sebesar 1920, nilai maksimal sebesar 3360, dan rata-rata skor sebesar 5,21 dan Kriteria posisi sebesar 74,43\%. Kriteria $74,43 \%$ termasuk di posisi $69 \%$ - 83\% (sangat baik).

Komitmen organisasi, dalam penelitian ini untuk menilai komitmen organisasi digunakan 9 pertanyaan. total skor jawaban responden diperoleh sebesar 3974 dengan nilai minimal sebesar 2160, nilai maksimal sebesar 5040, dan rata-rata skor sebesar 5,52 dan kriteria posisi sebesar 78,85\%. Kriteria 78,85\% termasuk di posisi 69\% - 83\% (sangat baik).

Gaya kepemimpinan berorientasi tugas, dalam penelitian ini untuk menilai gaya kepemimpinan berorientasi tugas digunakan 9 pertanyaan. Total skor jawaban responden diperoleh sebesar 3738 dengan nilai minimal sebesar 1440, nilai maksimal sebesar 5040, dan rata-rata skor sebesar 5,19. Dan kriteria posisi sebesar 74,17\%. Kriteria $74,17 \%$ termasuk di posisi $69 \%-83 \%$ (sangat baik).

Gaya Kepemimpinan Berorientasi Hubungan, dalam penelitian ini untuk menilai gaya kepemimpinan berorientasi digunakan 8 pertanyaan. Total skor jawaban responden diperoleh sebesar 3246 dengan nilai minimal sebesar 1280, nilai maksimal sebesar 4480, dan rata-rata skor sebesar 5,07 dan kriteria posisi sebesar 72,45\%. Kriteria 72,45\% termasuk di posisi 69\% - 83\% (sangat baik).

\section{Uji Kualitas Data}

Hasil pengujian validitas data untuk variabel kinerja manajerial, partisipasi anggaran, komitmen organisasi, gaya kepemimpinan berorientasi 
tugas dan gaya kepemimpinan berorientasi hubungan yaitu diperoleh nilai $\mathrm{r}$ tabel dengan persamaan $\mathrm{N}-2=80-2=78=0,220$. Nilai $r$ hitung dalam uji ini adalah pada kolom Corrected Item Total Correlation. Diketahui nilai $r$ hitung > 0,220. Artinya seluruh item variabel kinerja manajerial, partisipasi anggaran, komitmen organisasi, gaya kepemimpinan berorientasi tugas dan gaya kepemimpinan berorientasi hubungan dinyatakan valid.

Reliabilitas data diuji dengan statistik Cronbach's Alpha (a). Suatu konstruk variabel dikatakan baik jika memiliki nilai Cronbach's Alpha > o,6o. Berdasarkan hasil pengujian, Cronbach's Alpha untuk variabel kinerja manajerial sebesar $0,706>0,60$, partisipasi anggaran sebesar $0,740>0,60$, komitmen organisasi sebesar $0,637>0,60$, gaya kepemimpina berorientasi tugas sebesar $o, 626>0,60$ dan gaya kepemimpinan berorientasi hubungan sebsesar $0,696>$ o,60 sehingga dapat disimpulkan bahwa alat ukur yang digunakan dalam penelitian ini reliabel karena Cronbach's Alpha > o,6o.

\section{Uji Asumsi Klasik}

Suatu model dikatakan bebas dari adanya multikolinearitas apabila nilai toleransi $>0,1$ atau sama dengan nilai VIF $<10$ berarti tidak ada multikolinearitas antar variabel dalam model regresi (Ghozali, 2005). Hasil pengujian menjelaskan bahwa diperoleh nilai VIF untuk seluruh variabel bebas < 10 dan tolerance $>0,10$. Hal ini dapat disimpulkan bahwa model regresi tersebut bebas dari multikolinieritas.

Hasil yang diperoleh dilihat dari nilai d sebesar 2,001 dan ternyata lebih besar dari batas atas (dU) yaitu sebesar 1,7430 dan kurang dari 4 - 1,7430 (4 dU) atau 1,7430 < 2,001 < 4- 1,7430 sehingga didapat hasil akhirnya atau 1,7430 $<2,001<2,257$ atau $\mathrm{dU}<\mathrm{d}<4$-dU. Sehingga dapat disimpulkan bahwa tidak terdapat autokorelasi baik positif maupun negatif sehingga Ho diterima dan layak digunakan dalam penelitian.

Untuk mendeteksi ada tidaknya heterokedastisitas dapat dilihat dari ada tidaknya pola tertentu pada grafik scatterplot. Jika membentuk pola tertentu, maka terdapat heterokedastisitas dan jika titik-titiknya menyebar, maka tidak terdapat heterokedastisitas. Hasil pengujian heterokedastisitas dapat dilihat pada Gambar 1:

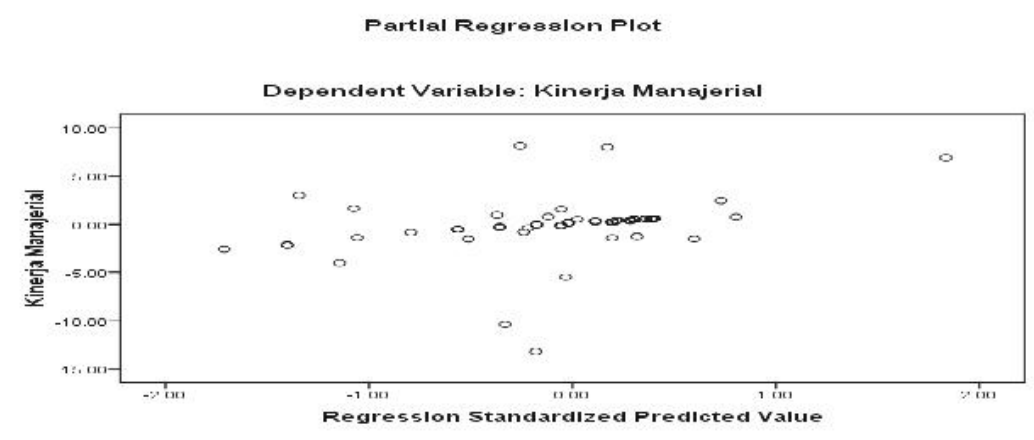

Gambar 1: Hasil Uji Heteroskedastisitas 
Jika data menyebar disekitar garis diagonal maka model regresi memenuhi asumsi normalitas. Sedangkan jika data menyebar jauh dari garis diagonal, maka model regresi tidak memenuhi asumsi normalitas. Dari gambar IV.2 dapat dilihat bahwa sebaran data berada disekitar garis diagonal dan mengikuti garis diagonal. Oleh karena itu model regresi dalam penelitian ini memenuhi asumsi normalitas. normal probability plot pada penelitian ini tampak pada Gambar 2 :

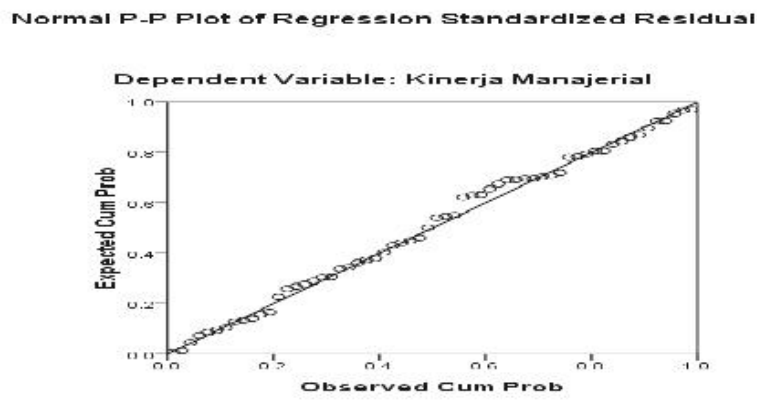

\section{Gambar 2: Hasil Uji Normalitas Data}

\section{Hasil Analisis Regresi}

Persamaan regresi yang diperoleh dari hasil pengujian hipotesis pertama adalah sebagai berikut : $\mathrm{Y}=55,024+0,871 \mathrm{X}_{1}$

Persamaan regresi yang diperoleh dari hasil pengujian hipotesis kedua adalah sebagai berikut : $\mathrm{Y}=4,553+0,055 \mathrm{X}_{1}+0,199 \mathrm{X}_{2}+0,079 \mathrm{X}_{1} \mathrm{X}_{2}$

Persamaan regresi yang diperoleh dari hasil pengujian hipotesis ketiga adalah sebagai berikut : $\mathrm{Y}=3,019+0,002 \mathrm{X}_{1}+0,249 \mathrm{X}_{3}+0,038 \mathrm{X}_{1} \mathrm{X}_{3}$

Persamaan regresi yang diperoleh dari hasil pengujian hipotesis keempat adalah sebagai berikut : $\mathrm{Y}=3,433+0,045 \mathrm{X}_{1}+0,190 \mathrm{X}_{4}+0,046 \mathrm{X}_{1} \mathrm{X}_{4}$

\section{Hasil Koefisien Determinasi}

Dari hasil uji kooefisien determinasi untuk hipotesis pertama diperoleh nilai sebesar 0.699. Angka ini menjelaskan bahwa 69\% kinerja manajerial dipengaruhi partisipasi anggaran sedangkan sisanya $31 \%$ kinerja manajerial dijelaskan oleh variabel lainnya, seperti wewenang, kecukupan anggaran, budaya organisasi, komitmen tujuan anggaran, desentralisasi, locus of control dan lainlain.

Dari hasil uji kooefisien determinasi untuk hipotesis kedua sebesar 0,655 (65\%). Hipotesis ketiga sebesar 0,643 (64\%). Hipotesis keempat sebesar 0,659 (65\%). Angka ini menjelaskan bahwa dengan nilai persentase masing-masing hipotesis tersebut kinerja manajerial dipengaruhi partisipasi anggaran, komitmen organisasi, gaya kepemimpinan berorientasi tugas dan gaya kepemimpinan berorientasi hubungan. Sedangkan sisanya untuk hipotesis pertama sebesar $31 \%$, hipotesis kedua sebesar 35\%, hipotesis ketiga sebesar $36 \%$ 
dan hipotesis keempat sebesar 35\% dijelaskan oleh variabel seperti seperti wewenang, kecukupan anggaran, budaya organisasi, komitmen tujuan anggaran, desentralisasi, locus of control dan lain-lain.

\section{Pembahasan}

Hasil pengolahan data diketahui t hitung $(13,472)>t$ tabel $(1,990)$ dan nilai signifikan sebesar 0,002 dengan tingkat kesalahan (alpha) sebesar 0.05. Oleh karena itu dapat disimpulkan bahwa partisipasi anggaran berpengaruh signifikan terhadap kinerja manajerial.

Hasil pengolahan data diketahui $t$ hitung $(5,091)>t$ tabel $(1,990)$ dan nilai signifikan sebesar o,ooo dengan tingkat kesalahan (alpha) sebesar 0.05. Oleh karena itu dapat disimpulkan bahwa partisipasi anggaran yang dimoderasi oleh komitmen organisasi berpengaruh signifikan terhadap kinerja manajerial.

Hasil pengolahan data diketahui t hitung $(2,046)>t$ tabel $(1,990)$ dan nilai signifikan sebesar 0,044 dengan tingkat kesalahan (alpha) sebesar 0.05. Oleh karena itu dapat disimpulkan bahwa partisipasi anggaran yang dimoderasi oleh gaya kepemimpinan berorientasi tugas berpengaruh signifikan terhadap kinerja manajerial.

Hasil pengolahan data diketahui $t$ hitung $(2,521)>t$ tabel $(1,990)$ dan nilai signifikan sebesar 0,014 dengan tingkat kesalahan (alpha) sebesar 0.05. Oleh karena itu dapat disimpulkan bahwa partisipasi anggaran yang dimoderasi oleh gaya kepemimpinan berorientasi hubungan berpengaruh signifikan terhadap kinerja manajerial.

\section{PENUTUP}

\section{Kesimpulan}

1. Berdasarkan hasil uji dari hipotesis pertama dapat dilihat bahwa partisipasi penyusunan anggaran berpengaruh signifikan terhadap kinerja manajerial, dengan melihat signifikansi sebesar 0,002 (0,002 < 0,05).

2. Berdasarkan hasil uji hipotesis kedua dapat dilihat bahwa komitmen organisasi berpengaruh terhadap hubungan antara partisipasi penyusunan anggaran dengan kinerja manajerial. Hal ini dibuktikan dengan nilai signifikansi sebesar $0,000(0,000<0,5)$.

3. Berdasarkan hasil uji hipotesis ketiga dapat dilihat bahwa gaya kepemimpinan berorientasi tugas berpengaruh terhadap hubungan antara partisipasi penyusunan anggaran dengan kinerja manajerial. Hal ini dibuktikan dengan nilai signifikansi sebesar 0,044 (0,044<0,5).

4. Berdasarkan hasil uji hipotesis keempat dapat dilihat bahwa gaya kepemimpinan berorientasi hubungan berpengaruh terhadap hubungan 
antara partisipasi penyusunan anggaran dengan kinerja manajerial. Hal ini dibuktikan dengan nilai signifikansi sebesar 0,014 (0,014 < 0,5).

5. Berdasarkan hasil koefisien determinasi untuk hipotesis pertama diperoleh nilai koefisien determinasi sebesar 0.696. Angka ini menjelaskan bahwa 69\% kinerja manajerial dipengaruhi partisipasi anggaran sedangkan sisanya $31 \%$ kinerja manajerial dijelaskan oleh variabel lainnya, seperti wewenang, kecukupan anggaran, budaya organisasi, komitmen tujuan anggaran, desentralisasi, locus of control dan lain-lain.

6. Berdasarkan hasil koefisien determinasi untuk hipotesis kedua sebesar o,656 (65\%). Hipotesis ketiga sebesar o,643 (64\%). Hipotesis keempat sebesar 0,659 (65\%). Angka ini menjelaskan bahwa dengan nilai persentase masing-masing hipotesis tersebut kinerja manajerial dipengaruhi partisipasi anggaran, komitmen organisasi, gaya kepemimpinan berorientasi tugas dan gaya kepemimpinan berorientasi hubungan. Sedangkan sisanya untuk hipotesis pertama sebesar $31 \%$, hipotesis kedua sebesar 35\%, hipotesis ketiga sebesar 36\% dan hipotesis keempat sebesar 35\% dijelaskan oleh variabel seperti seperti wewenang, kecukupan anggaran, budaya organisasi, komitmen tujuan anggaran, desentralisasi, locus of control dan lain-lain.

\section{Saran}

Bagi para manajer yang dilibatkan dalam proses penyusunan anggaran, hendaknya memahami partisipasi tersebut sebagai sebuah kesempatan untuk menyusun anggaran yang terbaik guna meningkatkan kinerjanya, bukan malah menjadi kesempatan untuk membuat anggaran yang lebih rendah dari kinerja yang sebenarnya mampu dicapai.

Untuk penelitian selanjutnya peneliti mengharapkan untuk mempertimbangkan variabel lainnya seperti job relevant information (JRI), kecukupan anggaran, budaya organisasi, desentralisasi dan lainnya yang akan mungkin mempengaruhi kinerja manajerial dan memperluas area penelitian, hal ini diperlukan untuk meningkatkan akurasi hasil yang diperoleh dimasa yang akan datang dapat lebih sempurna dari penelitian ini.

Kepada rumah sakit dalam rangka meningkatkan kinerja manajerial, kiranya meningkatkan komitmen organisasi dan gaya kepemimpinan para manajer maupun karyawan agar anggaran yang disusun dapat dilaksanakan dengan baik, serta melakukan penyelarasan komitmen pegawai terhadap instansi tempat mereka bekerja dalam usaha meningkatkan kinerja manajerial. 


\section{DAFTAR PUSTAKA}

Anthony, Robert N. dan Govindanrajan, Vijay. (Alih bahasa oleh: Kurniawan Tjakrawala dan Krista), 2005. Sistem Pengendalian Manajemen. Edisi 1. Jakarta. Salemba Empat.

Bambang Sardjito dan Osmad Muthaher. 2007. Pengaruh Partisipasi Penyusunan Anggaran Terhadap Kinerja Aparat Pemerintah Daerah : Budaya Organisasi Dan Komitmen Organisasi Sebagai Variabel Moderating. Simposium Nasional Akuntansi X. Makasar.

Brownell, P. dan McInnes, M., 1986. Budgetary Participation, Motivation, and Manajerial Performance. The Accounting Review, 61 (4)

Chong, Vincent K. dan Kar Ming Chong, 2002. Budget Goal Commitment and Informational Effects of Budget Participation on Performance": Astructural Equation Modeling Approach, Behavioral Research in Accounting. USA.

Daft, Richard L, 2010. Era Baru Manajemen. Buku 2. Edisi 9. Jakarta. Salemba Empat.

Ghozali, Imam, 2005. Aplikasi Analisis Multivariat dengan Program SPSS. Universitas Diponegoro. Semarang.

Govindarajan V, 1986. Impact of Participation in The Budgetary Process on Managerial Attitudes and Performance. Universalistic and Contigency Perspective. Decision Sciences 17. Hal. 496-516.

Indra, Bastian. 2005. Akuntansi Sektor Publik. Yogyakarta. BPFE.

Lubis, Arfan Ikhsan. 2010. Akuntansi Keperilakuan. Jakarta. Salemba Empat.

Mahoney, T. A, Jerdee and S.J Carroll. 1963. Development of managerial performance. A Research Approach. Cincinnati. Ohio: South Western Publishing Co.

Milani, Ken, 1975. The Relationship of Participation in Budget Setting to Industrial Supervisor Performance and Attitudes : A Field Study, The Accounting Review.

Nor, Wahyudin, 2007. Desentralisasi dan Gaya Kepemimpinan Sebagai Variabel Moderating Dalam Hubungan Antara Partisispasi Penyusunan Anggaran dan Kinerja Manajerial. Simposium Nasional Akuntansi $X$. Makasar.

Ridwan dan Sunarto, 2010. Rumus dan Data Dalam Analisis Statistika. Bandung. Alfabeta.

Sumadiyah dan Susanta. 2004. Job Relevant Information (JRI) dan Ketidakpastian Lingkungan dalam Hubungan Partisipasi Anggaran dan Kinerja Manajerial. Jurnal Ekonomi dan Bisnis Indonesia.

Sumarno, J. 2005. Pengaruh Komitmen Organisasi dan Gaya Kepemimpinan terhadap Hubungan antara Partisipasi Anggaran dan Kinerja Manajerial. Simposium Nasional Akuntansi VIII. Solo.

Supriyono, R.A. 2005. Pengaruh Komitmen Organisasi, Keinginan Sosial, dan Asimetri Informasi terhadap Hubungan Antara Partisipasi Penganggaran dengan Kinerja Manajer. Jurnal Ekonomi dan Bisnis Indonesia. 
Thoha, Miftah, 2008. Perilaku Organisasi Konsep Dasar dan Aplikasinya. Jakarta. Raja Grafindo Persada.

Vincent K, Chong dan Dareen M. Jhonson, 2007. Testing A Model of The Antecendents nad Consequences of Budgetary Participation on Job Performance. Accounting and Business Research, 37 (1). hal: 3-19. 